\title{
Struktur Komunitas Zooplankton di Bendungan Telaga Tunjung, Kabupaten Tabanan-Bali
}

\author{
Ni Wayan Desy Wahyudiati a*, I Wayan Arthana a, Gde Raka Angga Kartika a \\ a Program Studi Manajemen Sumberdaya Perairan, Fakultas Kelautan dan Perikanan, Universitas Udayana, Badung, Bali \\ * Penulis koresponden. Tel.: +62-812-366-100-84 \\ Alamat e-mail: desywahyudiati@gmail.com
}

Diterima (received) 11 Agustus 2016; disetujui (accepted) 3 Mei 2017; tersedia secara online (available online) 5 Mei 2017

\begin{abstract}
Zooplankton are the heterotroph aquatic organisms and has a week swimming. Zooplankton acts as the first consumer in the waters, which utilize phytoplankton as their food. This research located in Telaga Tunjung reservoir, Timpag Village, Kerambitan Subdistrict, Tabanan Regency. The reservoir is used for industry, irrigation and tourism development. The aim of the research was to determine the community structure of zooplankton in Telaga Tunjung reservoir. This research was conducted from January to February 2016. Water sampling was conducted twice with a sampling interval of 2 weeks in 4 stations. There was a total of 23 species of zooplankton found, consisting of 6 classes: Eurotatoria (8 genera), Ciliatea (1 genera), Branchiopoda (4 genera), Monogononta (1 genera), Tubulinea (1 genera) and Maxillopoda (3 genera). The most common species of zooplankton found in the sampling station were Polyarthra vulgaris (3.04 ind/l), Anuraeopsis coelata (1.28 ind/l), Keratella valga (0.43 ind/l), Vorticella sp. (0.49 ind/1), Diaphanosoma brachyurum (0.28 ind/l), Nauplius sp. (0.16 ind/l) and Megacyclops viridis (1.16 ind/l). The average abundance of zooplankton was $9.38 \mathrm{ind} / \mathrm{l}$. Based on the abundance of zooplankton, the trophic status of Telaga Tunjung reservoir is mesotrophic.
\end{abstract}

Keywords: community structure; mesotrophic; reservoir; zooplankton

\begin{abstract}
Abstrak
Zooplankton merupakan organisme akuatik yang bersifat heterotrof dan memiliki daya renang yang lemah. Zooplankton berperan sebagai konsumen pertama di dalam perairan, yang memanfaatkan fitoplankton sebagai makanannya. Penelitian ini dilaksanakan di Bendungan Telaga Tunjung, Desa Timpag, Kecamatan Kerambitan, Kabupaten Tabanan. Bendungan ini dimanfaatkan untuk keperluan industri, irigasi dan pengembangan kawasan pariwisata. Tujuan penelitian ini adalah untuk mengetahui struktur komunitas zooplankton di Bendungan Telaga Tunjung. Penelitian ini dilaksanakan pada bulan Januari-Februari 2016. Pengambilan sampel dilakukan setiap dua minggu sekali pada 4 stasiun. Tingginya kekeruhan perairan diduga sebagai penyebab rendahnya kelimpahan zooplankton. Total spesies zooplankton yang didapatkan sebanyak 23 spesies yang terdiri dari 6 kelas, yaitu Eurotatoria (8 genus), Ciliatea (1 genus), Branchiopoda (4 genus), Monogononta (1 genus), Tubulinea (1 genus) dan Maxillopoda (3 genus). Jenis zooplankton yang dominan ditemukan selama penelitian antara lain: Polyarthra vulgaris (3,04 ind/l), Anuraeopsis coelata (1,28 ind/l), Keratella valga (0,43 ind/l), Vorticella sp. (0,49 ind/l), Diaphanosoma brachyurum (0,28 ind/l), Nauplius sp. (0,16 ind/1) dan Megacyclops viridis (1,16 ind/l). Kelimpahan rata-rata zooplankton, yaitu sebesar 9,38 ind/l. Berdasarkan kelimpahan zooplankton, Bendungan Telaga Tunjung tergolong kedalam perairan yang memiliki tingkat kesuburan sedang (mesotrofik).
\end{abstract}

Kata Kunci: bendungan; mesotrofik; struktur komunitas; zooplankton

\section{Pendahuluan}

Bendungan Telaga Tunjung terletak di Desa Timpag, Kecamatan Kerambitan, Kabupaten Tabanan, Provinsi Bali. Tujuan dibangun bendungan ini adalah untuk keperluan industri, irigasi dan pengembangan kawasan pariwisata. Pada Bendungan Telaga Tunjung terdapat dua sungai yang bermuara pada bendungan ini, yaitu Sungai Yeh Mawa dan Sungai Yeh Ho. Pada hulu 
bendungan terdapat areal persawahan, perkebunan dan pemukiman (BWS Bali-Penida, 2015). Bendungan ini memiliki luas genangan waduk seluas 16,5 Ha dengan volume tampungan 1.261.000 $\mathrm{m}^{3}$ (Agra, 2006). Bupati Tabanan mencanangkan sebagian dari wilayah bendungan akan digunakan sebagai lokasi budidaya keramba jaring apung dan areal pemancingan (DPK Kabupaten Tabanan, 2007). Keberhasilan dalam mengembangkan kegiatan perikanan dipengaruhi oleh kualitas perairan. Kualitas perairan Bendungan Telaga Tunjung dipengaruhi oleh masukan bahan organik dari Sungai Yeh Ho dan Sungai Yeh Mawa serta aktivitas masyarakat yang berada disekitar bendungan maupun di sekitar daerah aliran sungai.

Zooplankton merupakan hewan akuatik yang memiliki daya renang yang lemah dan melayang di kolom perairan baik di lautan atau perairan tawar (Ferdous and Muktadir, 2009). Kesuburan dan kestabilan suatu perairan dapat dilihat dari keanekaragaman dan kelimpahan zooplankton (Rahayu dkk., 2013). Zooplankton berperan dalam mengatur kelimpahan fitoplankton melalui selektifitas makanan (food selectivity), yaitu mekanisme yang signifikan untuk mengontrol komposisi dari komunitas fitoplankton (Aziz et al., 2006). Oleh karena itu, zooplankton dapat dijadikan indikator kesuburan perairan, karena zooplankton berperan sebagai agen transfer energi dan indikator dari keberadaan fitoplankton (Ruga dkk., 2014). Beberapa spesies zooplankton seperti rotifera, branchiopoda dan copepoda dapat digunakan sebagai indikator kesuburan perairan (Duggan et al., 2003), karena komposisinya dipengaruhi oleh beberapa parameter lingkungan seperti, $\mathrm{pH}$, salinitas dan parameter biologi lainnya (Guess et al., 2003). Kesuburan perairan dapat digolongkan menjadi 3 berdasarkan kelimpahan zooplankton yaitu: kelimpahan zooplankton 1 ind/1 tergolong peraran oligotrofik, kelimpahan zooplankton 1-500 ind/1 tergolong perairan mesotrofik dan kelimpahan zooplankton lebih dari 500 ind/l tergolong peraraian eutrofik (Goldman and Horne (1994) dalam Suryanto dan Umi (2009)). Untuk mengetahui kestabilan ekosistem dan kesuburan perairan di Bendungan Telaga Tunjung, penelitian mengenai struktur komunitas zooplankton penting untuk dilakukan. Tujuan penelitian ini adalah untuk mengetahui struktur komunitas zooplankton di Bendungan Telaga Tunjung. Hal tersebut berguna untuk dijadikan data dasar dalam mengembangkan kegiatan perikanan di Bendungan Telaga Tunjung.

\section{Metode Penelitian}

\subsection{Waktu dan Lokasi Penelitian}

Penelitian ini dilaksanakan pada bulan Januari sampai dengan Februari 2016. Pengambilan data lapangan dilakukan di Bendungan Telaga Tunjung, Desa Timpag, Kecamatan Kerambitan, Kabupaten Tabanan (Gambar 1) sedangkan identifikasi plankton dilakukan di Laboratoriun Perikanan Fakultas Kelautan dan Perikanan Universitas Udayana. Pengambilan sampel dilakukan setiap dua minggu sekali (4 kali pengambilan sampel), kemudian dirata-ratakan per stasiun. Terdapat 4 stasiun pengambilan sampel, yaitu stasiun A, B, C dan D. Stasiun A berada pada inlet sungai tadah hujan. Stasiun B berada di inlet bendungan tempat masuknya Sungai Yeh Ho dan Sungai Yeh Mawa. Stasiun C berada di tengah-tengah bendungan dan stasiun $D$ berada di daerah yang dekat dengan outlet.

\subsection{Teknik Pengambilan Sampel}

Adapun alat yang dipergunakan dalam penelitian ini antara lain : Plankton net, DO meter, pH meter, Turbidity meter, GPS, Sedgwick rafter, pipet tetes, Opti lab, mikroskop, buku identifikasi plankton Suthers and Rissik (2009). Bahan yang dipergunakan antara lain: larutan formalin $4 \%$, larutan lugol 5\% dan es batu.

\subsection{Pengambilan Sampel Air dan Identifikasi Plankton}

Penentuan stasiun untuk melakukan pengambilan sampel air menggunakan metode purposive sampling. Pengambilan sampel plankton dilakukan dengan menggunakan metode filtration method. Air bendungan disaring sebanyak 1001 menggunakan plankton net berukuran $150 \mu$. Sampel air hasil penyaringan dimasukkan ke dalam botol sampel dan kemudian diberikan larutan lugol 5\% dan larutan formalin 4\%. Sampel air dipasangkan kertas label yang berisi keterangan stasiun, jenis sampel dan waktu pengambilan sampel, kemudian sampel dimasukkan ke dalam coolbox yang terisi es batu. Identifikasi plankton dilakukan di bawah mikroskop binokuler dengan pembesaran $10 \times 10$, sebelum air sampel diteteskan pada Sedgwick rafter air sampel dikocok terlebih 
dahulu, hal ini dilakukan agar plankton yang terdapat di dalam botol tersebar merata dan mempunyai kesempatan terambil yang sama. Pengamatan dimulai dengan menentukan fokus untuk pencarian garis kotak-kotak pada Sedgwick rafter, kemudian mengamati plankton dengan menyisir kotak Sedgwick rafter dari ujung kiri atas sampai ujung kanan bawah dan menghitung banyaknya plankton yang tercacah. Plankton yang telah diamati diidentifikasi menggunakan buku identifikasi dan jurnal plankton air tawar.

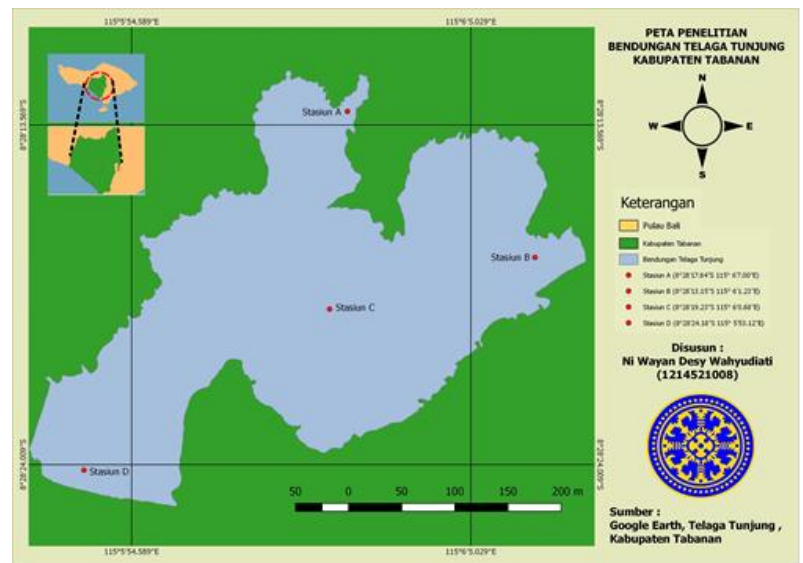

Gambar 1. Peta lokasi penelitian

\subsection{Tahapan Analisis}

Tahapan analisis dilakukan setelah mengidentifikasi jenis-jenis plankton yang ditemukan sehingga dapat dilakukan perhitungan untuk mencari nilai kelimpahan plankton, indeks keanekaragaman, indeks keseragaman dan indeks dominansi.

\section{a. Kelimpahan plankton (N)}

Perhitungan kelimpahan plankton per liter dilakukan dengan menggunakan formulasi APHA (2005), yaitu:

$$
\mathrm{N}=n \times \frac{A}{B} \times \frac{C}{D} \times \frac{1}{E}
$$

Keterangan :

A = Jumlah kotak pada Sedgewick Rafter

$\mathrm{B}=$ Jumlah kotak yang diamati

$\mathrm{C}=$ Volume air sampel yang tersaring $(\mathrm{ml})$

$\mathrm{D}=$ Volume air sampel yang diamati $(\mathrm{ml})$

$\mathrm{E}=$ Volume air yang disaring (l)

$\mathrm{N}=$ Kelimpahan (sel/l)

$\mathrm{n}$ = Jumlah individu per lapang pandang b. Indeks keanekaragaman $\left(\mathrm{H}^{\prime}\right)$

Keanekaragaman zooplankton dihitung menggunakan persamaan indeks Shannon-Wiener (Odum, 1993) :

$$
H^{\prime}=-\sum_{i=1}^{n} P_{i} \ln P_{i}
$$

Keterangan :

$\mathrm{H}^{\prime}=$ Indeks keanekaragaman

$\mathrm{Pi}=\mathrm{ni} / \mathrm{N}$

$\mathrm{ni}=$ Jumlah individu jenis ke-i

$\mathrm{N}=$ Jumlah total individu

c. Indeks keseragaman (E)

Indeks keseragaman dapat dihitung dengan persamaan indeks keseragaman Shannon-Wiener (Odum, 1993), yaitu sebagai berikut :

$$
E=\frac{H^{\prime}}{H m a k s}
$$

Keterangan :

$\mathrm{E}=$ Indeks keseragaman

$\mathrm{H}^{\prime}$ = Indeks keanekaragaman Shannon-Wiener

$\mathrm{S}=$ Jumlah genus yang ditemukan

Hmaks = Ln S (indeks keanekaragaman maksimum)

d. Indeks dominansi (C)

Indeks dominansi dapat dihitung menggunakan persamaan Indeks Dominansi Simpson (Odum, 1993), yaitu sebagai berikut :

$$
C=\sum_{i=1}^{n}\left(n_{i} / N\right)^{2}
$$

Keterangan :

$\mathrm{C}=$ Indeks dominansi Simpson

ni $=$ Jumlah individu jenis ke-i

$\mathrm{N}=$ Jumlah total individu

$\mathrm{S}=$ Jumlah genus

\subsection{Metode pembuatan peta kelimpahan zooplankton}

Hasil dari analisis data plankton pada penelitian ini dibuatkan sebuah peta persebaran plankton sesuai dengan kelimpahannya di Bendungan Telaga Tunjung. Proses pembuatan peta menggunakan software Quantum GIS dan Google 
Earth (Alifianto dkk., 2013). Metode yang digunakan adalah Inverse Distance Weighted (IDW). Asumsi dari metode IDW adalah data sampel yang lokasinya berdekatan nilai interpolasinya akan lebih mirip dibandingkan dengan data sampel yang lokasinya lebih jauh (Hadi, 2013).

\section{Hasil dan Pembahasan}

\subsection{Struktur Komunitas Zooplankton}

Hasil pengamatan mikroskopis menunjukkan bahwa Zooplankton yang didapatkan terdiri dari 6 kelas, yaitu Eurotatoria (8 genus), Ciliatea (1 genus), Branchiopoda (4 genus), Monogononta (1 genus), Tubulinea (1 genus) dan Maxillopoda (3 genus). Pada stasiun A ditemukan sebanyak 18 spesies, di stasiun B sebanyak 15 spesies, di stasiun C sebanyak 15 spesies dan di stasiun D sebanyak 10 spesies. Terdapat beberapa spesies yang ditemukan pada keempat stasiun selama penelitian, yaitu Keratella valga, Anuraeopsis navicula, Anuraeopsis coelata, Polyarthra vulgaris, Philodina plena, Vorticella sp., Diaphanosoma brachyurum, Nauplius sp. dan Megacyclops viridis.

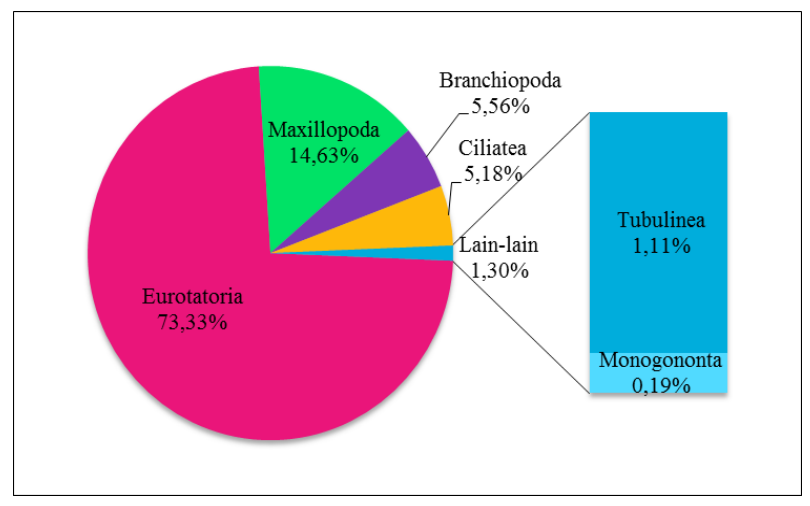

Gambar 2. Komposisi (\%) zooplankton berdasarkan kelimpahan masing-masing kelas di Bendungan Telaga Tunjung

Gambar 2 menunjukkan komposisi zooplankton di Bendungan Telaga Tunjung didominasi oleh kelas Eurotatoria, yaitu 73,33\% sedangkan komposisi terkecil adalah kelas Monogononta, yaitu 0,19\%. Kelas Maxillopoda ditemukan sebanyak 14,63\%, sedangkan kelas Branchiopoda dan Ciliatea komposisinya ditemukan hampir sama, yaitu berturut-turut $5,56 \%$ dan 5,18\%. Kelas Tubulinea ditemukan dalam komposisi rendah, yaitu $1,11 \%$. Kelas Eurotatoria yang berasal dari filum Rotifera memiliki penyebaran spesies yang luas di
Bendungan Telaga Tunjung. Hal tersebut didukung oleh pernyataan Zamroni dkk. (2011), bahwa filum Rotifera dan Crustacea merupakan dua kelompok besar yang umum ditemukan di perairan tawar.

\subsection{Kelimpahan Zooplankton}

Kelimpahan zooplankton di Bendungan Telaga Tunjung berkisar antara 6,74-11,60 ind/1 (Tabel 1). Sebaran kelimpahan zooplankton di Bendungan Telaga Tunjung dapat dilihat pada Gambar 3. Kelimpahan tertinggi didapatkan pada stasiun C, yaitu sebesar 11,60 ind/l, sedangkan kelimpahan terendah didapatkan pada stasiun D. Rendahnya kelimpahan zooplankton di stasiun D kemungkinan disebabkan karena rendahnya kelimpahan fitoplankton. Menurut Faiqoh dkk. (2015), bahwa ketika fitoplankton menurun, jumlah zooplankton akan menurun karena kekurangan makanan. Fitoplankton merupakan makanan zooplankton herbivor. Selain itu, kelimpahan zooplankton juga dipengaruhi oleh ikan-ikan pemakan zooplankton. Hal tersebut didukung oleh pendapat Redden et al. (2008) bahwa ketersediaan fitoplankton dan ikan-ikan pemakan zooplankton mempengaruhi populasi zooplankton.

Kelimpahan rata-rata zooplankton di Bendungan Telaga Tunjung didapatkan sebesar 9,38 ind/1 (Tabel 1). Hal tersebut mengindikasikan status kesuburan perairannya tergolong sedang (mesotrofik). Kelimpahan zooplankton di Waduk Lahor juga menunjukkan tingkat kesuburan perairan yang tergolong mesotrofik dengan kelimpahan zooplankton berkisar antara 4996 14275 ind/l (Suryanto dan Umi, 2009).

Spesies dominan dari masing-masing kelompok zooplankton pada keempat stasiun di Bendungan Telaga Tunjung. Terdapat 4 kelas yang mendominasi pada perairan tersebut, yaitu Eurotatoria, Ciliatea, Branchiopoda dan Maxillopoda. Pada kelas Eurotatoria, didominasi oleh spesies Polyarthra vulgaris $(3,04$ ind/l), Anuraeopsis coelata $(1,28 \mathrm{ind} / \mathrm{l})$ dan Keratella valga $(0,43$ ind/l). Genus Keratella dan Anuraeopsis juga ditemukan di Waduk Krenceng, Cilegon, Banten (Handayani dan Patria, 2005). Di Muara Sungai Serang, Yogyakarta juga ditemukan genus Keratella dan Polyarthra (Pranoto dkk., 2005). 
Tabel 1

Jenis dan kelimpahan rata-rata zooplankton (ind/l) yang ditemukan di Bendungan Telaga Tunjung

\begin{tabular}{lll}
\hline No & Nama Spesies & Rata-rata \\
\hline
\end{tabular}

\section{Eurotatoria}

$\begin{array}{cl}1 & \text { Keratella valga } \\ 2 & \text { Anuraeopsis navicula } \\ 3 & \text { Anuraeopsis coelata } \\ 4 & \text { Anuraeopsis fissa } \\ 5 & \text { Polyarthra vulgaris } \\ 6 & \text { Philodina plena } \\ 7 & \text { Collotheca crateriformis } \\ 8 & \text { Brachionus plicatilis } \\ 9 & \text { Lecane sp. } \\ 10 & \text { Trichocerca multicrinis }\end{array}$

Total

Ciliatea

$1 \quad$ Vorticella sp.

$0,49^{*}$

Branchiopoda

$\begin{array}{ll}1 & \text { Diaphanosoma aspinosum } \\ 2 & \text { Diaphanosoma brachyurum } \\ 3 & \text { Diaphanosoma birgei } \\ 4 & \text { Acroperus harpae } \\ 5 & \text { Pleopis polyphemoides } \\ 6 & \text { Moina macrocopa }\end{array}$

Total

0,49

0,12

$0,28^{*}$

0,05

0,02

0,02

0,04

0,52

Tubulinea

$$
1 \text { Arcella vulgaris }
$$

2 Arcella crenulata

Total

Total

0,10

Monogononta

\section{Asplanchna herricki}

0,02

Total $\quad 0,02$

Maxillopoda

$1 \quad$ Nauplius sp.

$0,16^{*}$

2 Mesocyclops edax

3 Megacyclops viridis

0,05

$1,16^{*}$

\begin{tabular}{lll} 
& Total & 1,37 \\
\hline Rata-rata total & 9,38
\end{tabular}

Jumlah spesies

14,50

Indeks Keanekaragaman (H')

0,88

Indeks Keseragaman (E)

0,45

Indeks Dominansi (C)

Keterangan :

* = spesies dominan dari masing-masing kelompok zooplankton yang ditemukan pada keempat stasiun selama penelitian di Bendungan Telaga Tunjung
Pada kelas Ciliatea hanya ditemukan 1 spesies yang mendominasi pada perairan Bendungan Telaga Tunjung, yaitu Vorticella sp. (0,49 ind/l). Vorticella sp. juga ditemukan sebagai parasit pada ikan di Danau Lais, Kalimantan Tengah (Rosita, 2012). Pada kelas Branchiopoda hanya ditemukan Diaphanosoma brachyurum (0.28 ind/l) yang ditemukan pada keempat stasiun penelitian. Diaphanosoma brachyurum juga umum ditemukan di perairan tawar di Korea Selatan bagian tenggara dan mendominasi pada musim panas (Choi et al., 2015). Pada kelas Maxillopoda, ditemukan 2 spesies yang sering ditemukan pada keempat stasiun, yaitu Nauplius sp. (0,16 ind/l) dan Megacyclops viridis (1,16 ind/l). Nauplius sp. juga ditemukan di Danau Opi Jakabaring, Palembang (Kusmeri dan Rosanti, 2015). Megacyclops viridis juga ditemukan di Danau Orta, Italia (Bonacina and Pasteris, 2001).

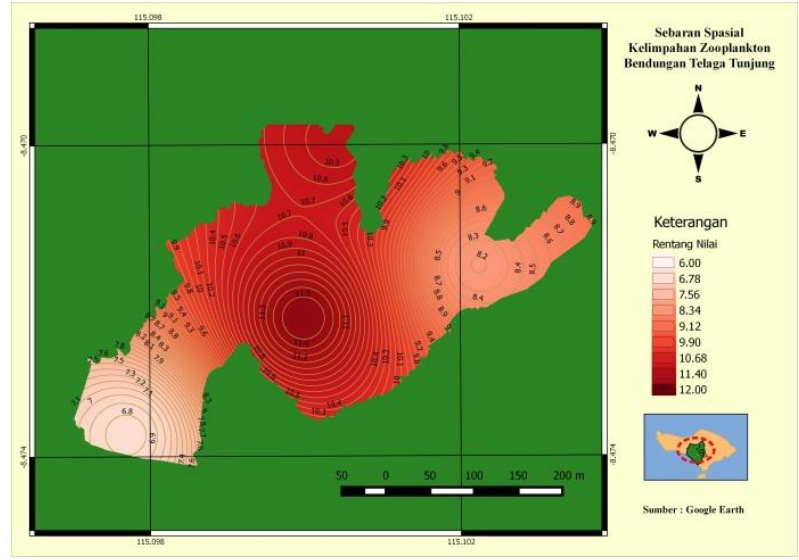

Gambar 3. Peta sebaran kelimpahan zooplankton di Bendungan Telaga Tunjung

\subsection{Indeks Struktur Spesies}

a. Indeks Keanekaragaman Zooplankton

Nilai indeks keanekaragaman zooplankton di Bendungan Telaga Tunjung berkisar antara 0 - 2,15 (Gambar 4). Nilai keanekaragaman 0 didapatkan pada sampling keempat di stasiun $\mathrm{D}$, sedangkan nilai tertinggi didapatkan pada sampling pertama di stasiun A, yaitu 2,15. Pola keanekaragaman zooplankton pada stasiun A dan D mengalami penurunan pada setiap sampling. Pada stasiun B, pola keanekaragaman zooplankton meningkat pada sampling kedua dan turun pada sampling keempat. Sedangkan pada stasiun C, nilai keanekaragaman zooplankton tidak mengalami perubahan yang signifikan. Pada sampling ketiga 
tidak ditemukan zooplankton di setiap stasiun, begitupula pada sampling keempat di stasiun A dan $\mathrm{C}$ tidak ditemukan zooplankton.

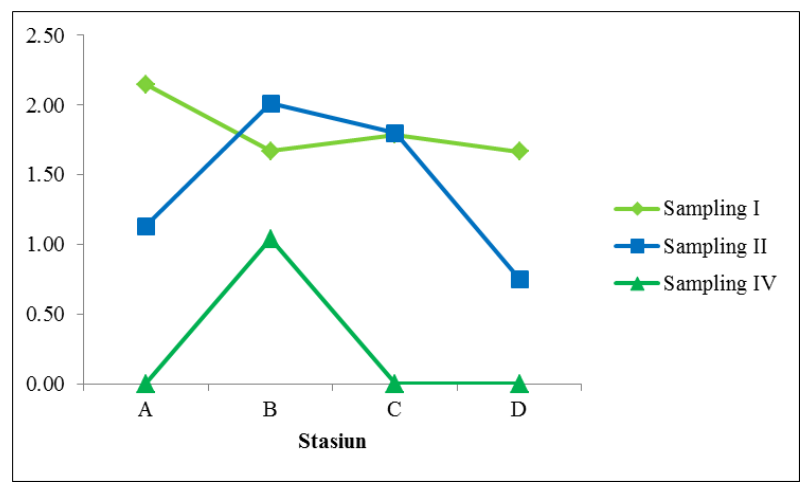

Gambar 4. Indeks keanekaragaman zooplankton

Nilai rata-rata indeks keanekaragaman zooplankton didapatkan sebesar 0,88. Nilai tersebut menunjukkan rendahnya keanekaragaman zooplankton di Bendungan Telaga Tunjung yang berarti kestabilan komunitas zooplankton di Bendungan Telaga Tunjung tergolong rendah. Nilai indeks keanekaragaman tertinggi didapatkan pada stasiun B dan terendah pada stasiun D.

\section{b. Indeks Keseragaman Zooplankton}

Nilai indeks keseragaman zooplankton berkisar antara $0-0,95$ (Gambar 5). Keseragaman tertinggi didapatkan pada sampling keempat di stasiun B, sedangkan nilai keseragaman 0 didapatkan pada sampling keempat di stasiun D. Pola keseragaman zooplankton pada stasiun $\mathrm{A}, \mathrm{C}$ dan $\mathrm{D}$ mengalami penurunan pada setiap sampling. Berbeda dengan stasiun lainnya, di stasiun B, pola keseragaman meningkat pada setiap sampling.

Nilai rata-rata indeks keseragaman zooplankton didapatkan sebesar 0,45 . Hal tersebut menunjukkan keseragaman zooplankton di Bendungan Telaga Tunjung memiliki kecenderungan sedang, karena mendekati 0,5. Hal tersebut terjadi karena persebaran spesies pada tiap genus hampir merata dengan spesies yang beranekaragam. Nilai indeks keseragaman tertinggi didapatkan pada stasiun B dan terendah pada stasiun D.

\section{c. Indeks Dominansi Zooplankton}

Nilai indeks dominansi berkisar antara 0,16 - 1,00 (Gambar 6). Nilai dominansi tertinggi didapatkan pada sampling keempat di stasiun $\mathrm{D}$, yaitu sebesar 1,00 , sedangkan nilai terendah didapatkan pada stasiun A (sampling pertama) dan stasiun B (sampling kedua). Pola dominansi pada stasiun A, $C$ dan $D$ menunjukan terjadinya peningkatan nilai indeks dominansi pada setiap sampling. Pada stasiun $B$, pola dominansi menurun pada sampling kedua dan meningkat kembali pada sampling keempat.

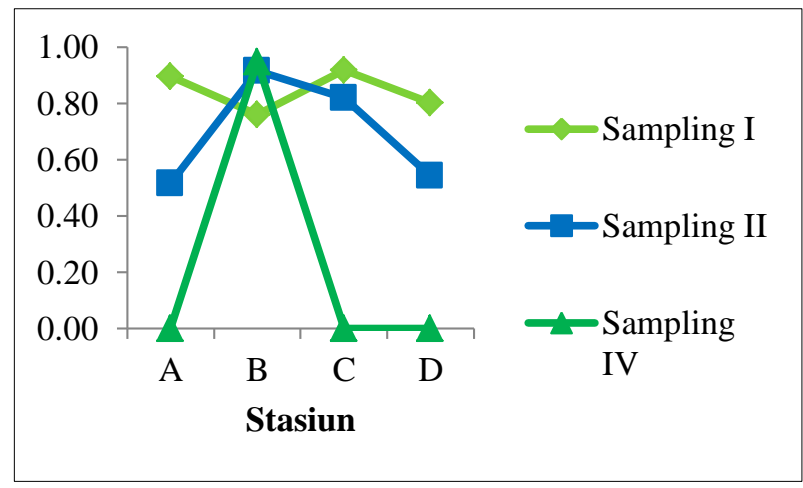

Gambar 5. Indeks keseragaman zooplankton

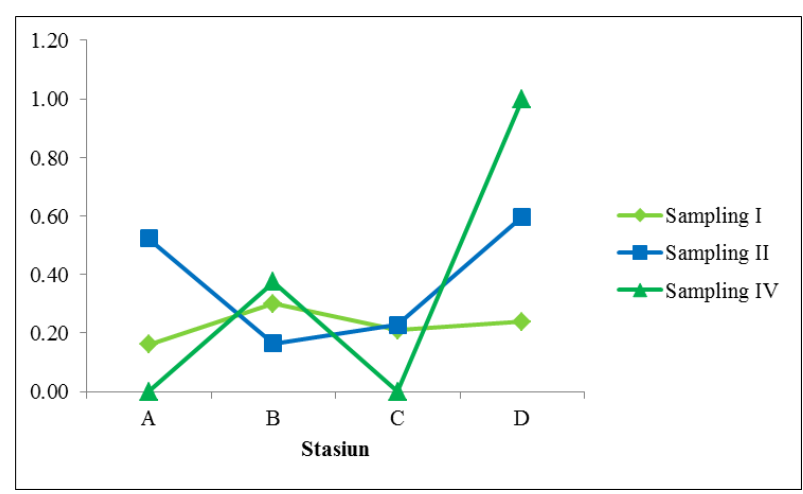

Gambar 6. Indeks dominansi zooplankton

Nilai rata-rata indeks dominansi didapatkan sebesar 0,24. Nilai indeks dominansi tersebut menunjukan dominansi zooplankton masih tergolong rendah, karena mendekati 0 . Hal tersebut menunjukkan tidak ada spesies zooplankton yang mendominansi di Bendungan Telaga Tunjung. Nilai indeks dominansi tertinggi didapatkan pada stasiun $\mathrm{D}$ dan terendah pada stasiun C.

\subsection{Kondisi Fisika Air di Bendungan Telaga Tunjung}

Hasil kualitas air yang didapatkan pada penelitian ini masih sesuai untuk kehidupan zooplankton. Nilai parameter fisik dapat dilihat pada Tabel 2. Kadar DO yang sesuai untuk kehidupan biota air termasuk zooplankton berkisar antara 5,45-7,00 
mg/l (Sanusi, 2004). Sedangkan kadar DO yang didapat berkisar antara 4,83-5,14 mg/l, kadar tersebut masih dapat ditolerir oleh zooplankton. Kadar DO kurang dari 2 mg/l dapat menyebabkan kematian pada organisme (Effendi, 2003). Nilai pH yang didapat berkisar antara 8,05-8,29. Nilai tersebut masih dapat menunjang kehidupan zooplankton. Biota perairan termasuk plankton dapat mentolerir nilai $\mathrm{pH}$ berkisar antara 6,6-8,5 (Welch, 1952). Suhu yang baik untuk kelimpahan zooplankton di daerah tropis secara umum berkisar ntara $24-30{ }^{\circ} \mathrm{C}$ (Dawson, 1979). Nilai suhu yang didapatkan berkisar antara 28,19-30,22 ${ }^{\circ} \mathrm{C}$. Nilai tersebut sedikit lebih tinggi dari suhu optimum zooplankton. Oleh karena itu, kemungkinan jenis zooplankton yang didapat adalah zooplankton yang dapat mentolerir suhu tersebut. Kadar kekeruhan yang didapat berkisar antara 31,35-38.00 NTU. Tingginya kadar kekeruhan diduga sebagai penyebab rendahnya kelimpahan zooplankton di Bendungan Telaga Tunjung. Kekeruhan sangat mempengaruhi proses fotosintesis fitoplankton di perairan, karena mengurangi masuknya penetrasi cahaya matahari sehingga menghambat proses fotosintesis fitoplankton. Hal tersebut dapat menurunkan kelimpahan fitoplankton kemudian diikuti dengan menurunnya kelimpahan zooplankton.

Tabel 2

Nilai Parameter Fisika Perairan

\begin{tabular}{lrrrr}
\hline \multirow{2}{*}{ Parameter } & \multicolumn{4}{c}{ Stasiun } \\
\cline { 2 - 5 } \multicolumn{1}{c}{ A } & \multicolumn{1}{c}{ B } & \multicolumn{1}{c}{ C } & \multicolumn{1}{c}{ D } \\
\hline DO $(\mathrm{mg} / \mathrm{l})$ & 5,11 & 5,07 & 4,83 & 5,14 \\
pH & 8,19 & 8,29 & 8,26 & 8,05 \\
Suhu $\left({ }^{\circ} \mathrm{C}\right)$ & 30,22 & 30,13 & 29,80 & 28,19 \\
Kekeruhan (NTU) & 38,00 & 31,35 & 35,20 & 35,05 \\
\hline
\end{tabular}

\section{Simpulan}

Kelimpahan rata-rata zooplankton pada setiap stasiun berkisar antara 6,74 - 11,60 ind/l. Sedangkan jumlah zooplankton yang didapat sebanyak 23 spesies yang terdiri dari 6 kelas, yaitu Eurotatoria (8 genus), Ciliatea (1 genus), Branchiopoda (4 genus), Monogononta (1 genus), Tubulinea (1 genus) dan Maxillopoda (3 genus). Komposisi zooplankton didominasi oleh Polyarthra vulgaris dari kelas Eurotatoria. Berdasarkan kelimpahan zooplankton, perairan Bendungan Telaga Tunjung tergolong kedalam perairan yang memiliki kesuburan sedang (mesotrofik). Perlu adanya penelitian lanjutan mengenai parameter lainnya yang mendukung untuk mengetahui kesesuaian pengembangan keramba jarring apung di Bendungan Telaga Tunjung.

\section{Daftar Pustaka}

Agra, I. G. G. M. (2006). Analisa Manfaat Biaya Pembangunan Bendungan Telaga Tunjung di Kabupaten Tabanan-Bali. Tugas Akhir. Jurusan Teknik Sipil Institut Teknologi Sepuluh Nopember: Surabaya.

Alifianto, F., Rodiyati, A., \& Brian, R. (2013). Peta Persebaran Porang (Amorphophallus muelleri Blume) Berdasarkan Topografi Wilayah di Malang Raya. Jurnal Biotropika, 1(2), 75-79.

American Publich Health Assosiation (APHA). (2005). Standard methods for the examination of water and waste water including bottom sediment and sludges. 21-st Edited: Eaton A.D, L.S Clesceri, E.W Rice and A.E Greenberg. Amer. Publ. Health Association Inc. New York. 1296 p.

Aziz, N. E., Gharib, S. M., \& Dorgham, M. M. (2006). The interaction between phytoplankton and zooplankton in a Lake-Sea connection, Alexandria, Egypt. International Journal of Oceans and Oceanography, 1(1), 151-165.

Bonacina, C. \& Pasteris, A. (2001). Zooplankton of Lake Orta After Liming: an Eleven Years Study. J. Limnology, 60(1), 101-109.

Choi, J. Y., Jeong, K. S., Kim, S. K., La, G. H, Chang, K. H., \& Joo, G. J. (2015). Spatio-temporal distribution of Diaphanosoma brachyurum (Cladocera: Sididae) in freshwater reservoir ecosystems: importance of maximum water depth and macrophyte beds for avoidance of fish predation. Journal Limnology, 74(2), 403-413.

Dawson, J. K. (1979). Copepods (Arthropoda: Crustacea: Copepoda). Pollution Ecology of Estuarine Invertebrates. Academic Press, pp. 145-170.

Duggan, I. C., Green, J. D. \& Shiel, R. J. (2003). Distribution of Rotifers in North Island, New Zealand, and Their Potential Use as Bioindicators of Lake Trophic State. Hydrobiologia, 446-447(1), 155-157.

Effendi, H. (2003). Telaah Kualitas Air Bagi Pengelolaan Sumberdaya dan Lingkungan Perairan. Penerbit Kanisius. Yogyakarta.

Faiqoh, E., Ayu, I. P., Subhan, B., Syamsuni, Y. F., Anggoro, A. W., \& Sembiring, A. (2015). Variasi Genetik Kelimpahan Zooplankton di Perairan Terganggu, Kepulauan Seribu, Indonesia. Journal of Marine and Aquatic Sciences, 1(1), 19-22.

Ferdous, Z. \& Muktadir, A. K. M. (2009). A review: Potentiality of Zooplankton as Bioindicator. American Journal of Applied Sciences, 6 (10), 1815-1819. 
Goldman, C. R. \& Horne, A. J. (1983). Limnology. Mc Graw Hill International Book Company. Tokyo.

Guess, S., Albrecht, D., Krambeck, H. J., MuellerNavarra, D. C., \& Mumm, H. (2003). Impact of Weather on Lake Ecosystem, Assessed by CycloStationary MCCA of Long-Term Observations. Ecology, 81(6), 1720-1730.

Hadi, B. S. 2013. Metode Interpolasi Spasial dalam Studi Geografi (Ulasan Singkat dan Contoh Aplikasinya). Geomedia, 11(2), 235-252.

Handayani, S. \& Patria, M. P. (2005). Komunitas Zooplankton di Perairan Waduk Kreceng, Cilegon, Banten. Jurnal Makara, Sains, 9(2), 75-80.

Kusmeri, L., \& Rosanti, D. (2015). Struktur Komunitas Zooplankton di Danau Opi Jakabaring Palembang. Jurnal Sainmatika, 12(1), 8-19.

Rahayu, S., Setyawati, T. R., \& Turnip, M. (2013). Struktur Komunitas Zooplankton di Muara Sungai Mempawah Kabupaten Pontianak Berdasarkan Pasang Surut Air Laut. Jurnal Protobiont, 2(2), 49-55.

Rosita. (2012). Identifikasi dan Dominasi Parasit pada Sumber Daya Ikan Hias di Danau Lais Kalimantan Tengah. Jurnal Ilmu Hewani Tropika, 1(2), 58-61.
Ruga, L., Langoy, M., Papu, A., \& Kolondam, B. (2014). Identifikasi Zooplankton di Perairan Pulau Bunaken Manado. Jurnal MIPA UNSRAT Online, 3(2), 84-86.

Sanusi, H. S. (2004). Karakteristik Kimiawi dan Kesuburan Perairan Teluk Pelabuhan Ratu pada Musim Barat dan Timur. Jurnal Ilmu-ilmu Perairan dan Perikanan Indonesia, 2(2), 93-100.

Suryanto, A. M. H., \& Umi, H. U. (2009). Pendugaan Status Trofik dengan Pendekatan Kelimpahan Fitoplankton dan Zooplankton di Waduk Sengguruh, Karangkates, Lahor, Wlingi Raya dan Wonorejo Jawa Timur. Jurnal Ilmiah Perikanan dan Kelautan, 1(1), 7-13.

Suthers, M. \& Rissik, D. (2009). Plankton - A Guide to Their Ecology and Monitoring for Water Quality. CSIRO Publishing. Australia.

Welch, P. S. (1952). Limnology. Mc. Graw - Hill publication. New York

Zamroni, M., Chumaidi \& Lita, A. W. (2011). Pengaruh Dosis Pemupukan dengan Menggunakan Pupuk Kotoran Ayam terhadap Kelimpahan dan Keanekaragaman Plankton pada Kolam Tanah. Prosiding Forum Inovasi Teknologi Akuakultur 2011, (pp. 845-842).

(C) 2017 by the authors; licensee Udayana University, Indonesia. This article is an open access article distributed under the terms and conditions of the Creative Commons Attribution license (http://creativecommons.org/licenses/by/3.0/). 